\title{
PENERAPAN PRINSIP PERBANKAN SYARIAH DALAM HUKUM DI INDONESIA
}

\author{
Muhamad Rifky Fernanda \\ Alumni Program Studi Magister Kenotariatan \\ Pascasarjana Universitas Islam Bandung \\ Email : fernanda.rifky1991@gmail.com
}

\begin{abstract}
Abstrak: Keuangan Syariah (LKS) saat ini telah berkembang dengan cukup pesat. Telah banyak varian dari LKS diseluruh Indonesia yaitu Bank Syariah. Bank Syari'ah adalah bank yang mendasarkan operasionalnya pada prinsip Syariah. Prinsip Syariah tersebut harus selalu dipatuhi oleh Bank Syariah mulai dari pendirian sampai dengan operasionalnnya, termasuk juga dalam hal permodalan Bank Syariah. Berkaitan dengan permodalan, modal Bank Syariah tidak boleh berasal dari sumber yang diharamkan secara Syariah, karena hal itu akan menyebabkan bercampurnya sesuatu yang haram dengan yang halal. Penelitian ini dilakukan dengan tujuan untuk memahami implementasi prinsip syariah pada Perbankan Syariah dan memahami penerapan prinsip syariah dalam permodalan bank syariah. Dengan menggunakan metode penelitian yuridis normatif. Hasil penelitian ini adalah bahwa penerapan prinsip syariah pada Lembaga perbankan syariah adalah wajib, dengan membentuk struktur pengawasan yang berlandaskan kepada fatwa Dewan Syariah Nasional (DSN), Undang-undang maupun peraturan lainnya. Serta penerapan prinsip syariah dalam permodalan syariah adalah dengan tidak bercampurnya sumber dana halal dengan sumber dana yang di haramkan menurut prinsip syariah.
\end{abstract}

\section{Kata Kunci: Prinsip Syari’ah, Lembaga Keuangan Syari’ah, Bank Syariah.}

Abstract: Sharia Financial Institution (LKS) is currently developing quite rapidly. There have been many variations of LKS throughout Indonesia, namely Sharia Bank that is a bank that bases its operations on sharia principles that must always be adhered to by Sharia Bank from its establishment until its operations, including in the case of Sharia Bank capital. With regard to capital, the Sharia Bank capital cannot come from sources that are prohibited by the sharia principles because it will cause the mixture of haram and halal items. In line with this, this study was conducted to comprehend the implementation of sharia principles in Sharia Banking and understand its implementation in Islamic banking capital. This study used a normative juridical method. The results revealed that the implementation of sharia principles to sharia banking institutions is mandatory, by establishing a supervisory structure based on the fatwas of National Sharia Board (DSN), laws, and other regulations. Additionally, the implementation of sharia principles in sharia banking capital is by not mixing the sources of halal and haram funds that are forbidden according to sharia principles.

Keywords: Sharia Principles, Sharia Financial Institution, Sharia Bank 


\section{PENDAHULUAN}

\section{A. Latar Belakang}

Seorang muslim di tuntut untuk hidup dalam bingkai dan koridor ketaatan kepada Allah Ta'ala dimana seorang muslim dalam ajaran agama Islam di larang atau diharamkan untuk memakan harta secara bathil (tidak benar), diantara bentuk memakan harta secara bathil adalah dengan cara mengambil riba atau bertransaksi dengan metode yang ribawi.

Prinsip Perbankan Syariah merupakan bagian dari ajaran Islam yang berkaitan dengan ekonomi. Salah satu prinsip dalam ekonomi Islam adalah larangan riba dalam berbagai bentuknya, dan menggunakan sistem antara lain prinsip bagi hasil. Dengan prinsip bagi hasil, Bank Syariah dapat menciptakan iklim investasi yang sehat dan adil karena semua pihak dapat saling berbagi baik keuntungan

maupun potensi risiko yang timbul sehingga akan menciptakan posisi yang berimbang antara bank dan nasabahnya. Dalam jangka panjang, hal ini akan mendorong pemerataan ekonomi nasional karena hasil keuntungan tidak hanya dinikmati DOI: https://doi.org/10.29313/aktualita.v0i0.5961 oleh pemilik modal saja, tetapi juga oleh pengelola modal. (Neni Sri Imaniyati, Pengaruh Perbankan Syariah Terhadap Hukum Perbankan Nasional, Fakultas Hukum Universitas Islam Bandung, Syiar Madani, Vo.Iv No. 1 Maret 2002 : 87).

Didalam Al Qur'an surah Ali Imran ayat 130 diterangkan bahwa "Hai orang-orang yang beriman, janganlah kaтu memakan riba dengan berlipat ganda dan bertakwalah kamu kepada Allah supaya kamu mendapat keberuntungan."

Ayat diatas adalah sebuah perintah tetapi perintahnya adalah untuk meninggalkan (perintah yang melarang melakukan sesuatu), Di dalam Ushul fiqh larangan terhadap sesuatu adalah perintah untuk berhenti mengerjakan sesuatu tersebut. Dalam hal ini larangan memakan riba berarti perintah untuk berhenti mengerjakan riba. Hukum asal larangan adalah pengharaman.

Prinsip Perbankan Syariah merupakan bagian dari ajaran Islam yang berkaitan dengan ekonomi. Salah satu prinsip dalam ekonomi Islam adalah larangan riba dalam berbagai bentuknya, dan menggunakan sistem antara lain prinsip bagi hasil. Dengan prinsip bagi hasil, Bank Syariah dapat menciptakan iklim investasi yang 
sehat dan adil karena semua pihak dapat saling berbagi baik keuntungan maupun potensi risiko yang timbul sehingga akan menciptakan posisi yang berimbang antara bank dan nasabahnya. Dalam jangka panjang, hal ini akan mendorong pemerataan ekonomi nasional karena hasil keuntungan tidak hanya dinikmati oleh pemilik modal saja, tetapi juga oleh pengelola modal. (Yusman Alim Djasmin Maku, Penerapan Prinsip-Prinsip Tentang Perbankan Syariah Hubungannya Dengan Otoritas Jasa Keuangan, Lex Crimen Vol. Vi/No. 1/Jan-Feb/2017).

Perbankan Syariah sebagai salah satu system perbankan nasional memerlukan berbagai sarana pendukung agar dapat memberikan kontribusi yang maksimum bagi pengembangan ekonomi nasional. Salah satu sarana pendukung vital adalah adanya pengaturan yang memadai dan sesuai dengan karakteristiknya. Pengaturan tersebut di antaranya dituangkan dalam Undang-Undang Perbankan Syariah. Pembentukan Undang-Undang Perbankan Syariah menjadi kebutuhan. Pengaturan mengenai Perbankan Syariah dalam UndangUndang Nomor 7 Tahun 1992 tentang DOI: https://doi.org/10.29313/aktualita.v0i0.5961
Perbankan sebagaimana telah diubah dengan Undang-Undang Nomor 10 Tahun 1998 belum spesifik dan kurang mengakomodasi karakteristik operasional Perbankan Syariah, kepastian hukum semakin dirasakan bagi masyarakat pengguna jasa perbankan syariah setelah diundangkannya Undang-Undang Nomor 21 Tahun 2008 tentang Perbankan Syariah. Satu tahapan besar yang ditunggu masyarakat telah dikeluarkan pemerintah dalam memberikan dukungannya bagi perkembangan perbankan syariah.

Pesatnya perkembangan Bank Syariah tersebut tidak lepas dari keunggulan-keunggulan yang dimiliki dan yang ditawarkan oleh Bank Syariah. Bank Syariah adalah bank yang dalam operasionalnya mendasarkan pada prinsip-prinsip Islam. Bank Syariah dalam melakukan kegiatan operasional perbankan tidak hanya untuk tujuan bisnis semata, yang berupa keuntungan materiil, tetapi juga mengejar kebahagiaan di akhirat. Untuk tujuan itu, Bank Syariah dalam melakukan kegiatan operasional perbankan tidak hanya mendasarkan pada ketentuan perbankan pada umumnya tetapi juga 
mendasarkan pada ketentuan Syariah.

Bank Syariah harus patuh pada prinsip-prinsip syariah yang terimplementasikan mulai dari pendirian sampai operasionalnya.

Permodalan Bank Syariah memegang peranan penting dalam menentukan Bank Syariah tersebut sudah memenuhi prinsip-prinsip syariah atau belum. Hal ini karena modal merupakan awal dari berdirinya Bank Syariah, apabila modal Bank Syariah tersebut berasal dari sumber yang diharamkan secara syariah, maka hal tersebut dapat mengurangi bahkan menghilangkan kehalalan kegiatan Bank Syariah tersebut. Tujuan yang baik harus dilakukan dengan cara yang baik. Dalam sistem ekonomi Islam dikenal adanya rambu-rambu tentang apa yang boleh dilakukan dan apa yang tidak boleh dilakukan. Rambu-rambu tersebut antara lain adalah: carilah yang halal lagi baik; tidak menggunakan cara yang batil; tidak berlebih-lebihan/ melampau batas; tidak di dzalimi maupun mendzalimi; menjauhkan diri dari unsur riba, maysir, (perjudiian dan intended speculatioan), dan gharar (ketidakjelasan dan manipulatif); serta tidak melupakan tanggung jawab DOI: https://doi.org/10.29313/aktualita.v0i0.5961 sosial berupa zakat, infak dan sedekah.

Berdasarkan hal tersebut diatas, maka penulis dapat membuat identifikasi masalah dalam pembahasan ini yaitu:

(1) Bagaimanakah Kondisi Penerapan Prinsip Syariah Oleh LKS Di Indonesia?

(2) Bagaimana Penerapan Prinsip Syariah Dalam Permodalan Bank Syariah?

Tujuan Penelitian dalam pembahasan ini yaitu:

(1) Untuk mengetahui dan menganalisis bagaimana implementasi prinsip-prinsip tentang Perbankan Syariah.

(2) Untuk mengetahui dan menganalisis hubungan kegiatan usaha perbankan syariah dengan Otoritas Jasa Keuangan.

\section{B. PEMBAHASAN}

\section{Penerapan Prinsip Syariah Dalam} Permodalan Bank Syariah.

(Arief Budiono, Penerapan Prinsip Syariah Pada Lembaga Keuangan Syariah, Universitas Muhammadiyah Ponorogo, Jurnal Law And Justice Vol. 2 No. 1 April 2017). 
1) Prinsip Al-Ta'awun

Merupakan prinsip untuk saling membantu dan bekerja sama. Dalam hal ini Allah Swt telah memerintahkan kepada manusia untuk berbuat saling tolong menolong dalam berbuat kebaikan dan takwa. Sebaliknya, Allah Swt melarang manusia untuk tolong menolong dalam hal perbuatan dosa dan pelanggaran, sebagaimana firman Allah dalam QS. AlMaidah: 2, yang artinya:

"Hai orang-orang yang beriman, janganlah kamu melanggar syi'ar-syi'ar Allah, dan jangan melanggar kehormatan bulan-bulan haram, jangan (mengganggu) binatang-binatang had-nya, dan binatang-binatang qalaaid, dan jangan (pula) menganggu orang-orang yang menjunjungi Baitullah sedang mereka mencari karunia dan keridhaan dari Tuhannya dan apabila kamu telah menyelesaikan ibadah haji, maka bolehlah berburu, dan janganlah sekali-kali kebencian (mu) kepada sesuatu kamu karena mereka menghalang-halangi kamu dari Masjidilharam, mendorongmu berbuat aniaya (kepada mereka). Dan tolong menolonglah kamu dalam (mengerjakan) kebajikan dan takwa, dan jangan tolong menolong dalam berbuat dosa dan pelanggaran. Dan bertakwalah kamu kepada Allah, sesungguhnya Allah amat berat siksa-Nya."

2) Prinsip Menghidar Al-Ikhtinaz

Prinsip ini sejalan dengan fungsi uang, yaitu tidak membiarkan uang menganggur dan tidak berputar dalam transaksi yang bermanfaat bagi masyarakat umum. Dalam pandangan Islam, uang adalah flow concept, oleh karena itu harus berputar dalam perekonomian. Semakin cepat uang berputar dalam perekonomian, maka akan semakin tinggi tingkat pendapatan masyarakat dan semakin baik perekonomiannya. (Rivai, Veithzal, Arviyan Arifin. 2010, : 299). Prinsip ini mendasarkan pada firman Allah Swt, yang tercantum dalam QS. An_Nisaa': 29, yang artinya: (Adiwarman A.Karim, 2007, :88)

"Hai orang-orang yang beriman, janganlah kamu saling memakan harta sesamemu dengan jalan yang batil, kecuali dengan jalan perniagaan yang berlaku dengan suka sama suka di antara kamu, janganlah kamu membunuh dirimu; sesungguhnya Allah adalah Maha Penyayang kepadamu." 
Dalam perbankan Syariah dilarang keras untuk melakukan transaksi apabila terdapat hal-hal sebagai berikut:

a. Gharar, yaitu adanya unsurunsur ketidakpastian atau tipu muslihat dalam transaksi.

b. Maysir, yaitu unsur judi yang transaksinya bersifat spekulatif yang dapat menimbulkan kerugian satu pihak dan keuntungan bagi pihak lain.

c. Riba, yaitu transaksi yang menggunakan sistem bunga.

(1) Modal Bank Syariah Berasal dari Sumber Yang Halal Menurut Syariah

Bank syariah adalah bank yang dimaksudkan untuk mengakomodasikan masyarakat yang ingin menjalankan Islam secara kaaffah, yaitu menghindari hal-hal yang dilarang oleh Agama Islam. Oleh karena itu, Bank syariah diwajibkan untuk patuh pada prinsip-prinsip syariah, sejak dari pendirian sampai pada operasionalnya, dalam hal ini termasuk dalam permodalannya. Menurut Islam, untuk melakukan sesuatu yang baik, harus diawali dengan yang baik juga.

DOI: https://doi.org/10.29313/aktualita.v0i0.5961
Demikian juga dengan konsep halal. Halal, menurut Islam, adalah halah dzatnya dan halal cara mendapatkannya. Daging ayam menurut Islam halal untuk dikonsumsi. Tetapi, apabila dalam mendapatkannya dilakukan dengan cara mencuri, maka daging ayam tersebut menjadi haram. Apabila cara menyembelihnya tidak sesuai dengan ajaran Islam, maka daging ayam tersebut juga haram untuk dikonsumsi.

Sebaliknya, daging babi secara dzatnya sudah haram. Meskipun cara mendapatkannya dengan cara membeli dengan menggunakan uang yang berasal dari kerja yang halal, daging babi tetaplah haram untuk dikonsumsi. Hal ini berlaku juga terhadap uang. Uang pada dasarnya merupakan sesuatu yang halal, tetapi jika mendapatkannya dengan cara mencuri atau merampok, maka uang tersebut menjadi haram untuk dimanfaatkan. Apabila uang tersebut digunakan untuk membeli ayam goreng, maka ayam goreng tersebut yang tadi halal menjadi haram untuk dikonsumsi. 
Bank syariah sebagaimana telah disebutkan diharapkan patuh pada prinsip-prinsip syariah, sehingga bank sebagai lembaga, dan hasil-hasil dari produknya halal secara agama. Demikian juga dengan dana yang digunakan untuk modal kegiatan usahanya juga harus halal secara syariah. Modal bank syariah tidak boleh berasal dari sumber-sumber yang dilarang oleh agama. (Abdul Ghofur Anshori, 2008, : 190-214).

Dana yang digunakan untuk modal bank syariah tidak boleh berasal dari hasil merampok, korupsi, hasil perjudian, hasil usaha minuman keras dan sebagainya yang bertetntangan dengan syariah, termasuk tidak boleh berasal dari hasil membungakan uang atau riba.

Menurut Pasal 9 ayat (1) UUPS ditentukan bahwa Bank Umum Syariah hanya dapat didirikan dan/atau dimiliki oleh:

a. Warga Negara Indonesia dan/atau badan hokum Indonesia;

b. Warga Negara Indonesia dan/atau badan hokum Indonesia dengan warga
Negara asing dan/atau badan hokum asing secara kemitraan; atau

c. Pemerintah daerah

(2) Tidak Bercampur Dengan Dana Yang Haram Menurut Syariah

Pemisahan antara uang yang haram dengan yang halal menurut ketentuan syariah malah terdapat dalam pasal 15 Peraturan Bank Indonesia Nomor: 8/3Pbi/2006 Tentang Perubahan Kegiatan Usaha Berdasarkan Prinsip Syariah Dan Pembukaan Kantor Bank Yang Melaksanakan Kegiatan Usaha Berdasarkan Prinsip Syariah Oleh Bank Umum Konvensional, yang menyatakan Bank yang memiliki Kantor Cabang Syariah wajib:

a. Memiliki pencatatan dan pembukuan tersendiri untuk kegiatan Usaha Berdasarkan Prinsip Syariah:

b. Menyusun laporan keuangan Kegiatan Usaha Berdasarkan Prinsip Syariah; dan

c. Memasukan laporan keuangan sebagaimana dimaksud dalam huruf $b$ ke dalam laporan keuangan gabungan. 
Pemisahan pencatatan dan pembukuan sebagaimana dimaksud dalam pasal 15 huruf a diatas adalah dimaksud agar tidak ada percampuran antara uang dari nasabah kantor Cabang yang menjalankan Prinsip Syariah dengan uang dari nasabah Konvensional. Menurut Lajnah Ad-Daa-amah lil Bubuuts Al'Ilmiyyah Wal Ifta (Komite Tetap Kajian Fatwa Ilmiah dan Pemberian Fatwa) kerajaan Saudi Arabia, secara tegas mengatakan bahwa membayar bunga pinjaman dengan menggunakan uang yang berasal dari bunga simpanan tidak diperkenankan. (M. Abdul, Ghoffar, 2004 : 392).

Fatwa di atas mendasarkan pada ketentuan yang ada dalam AlQuran, antara lain dalam surat AlBaqarah 276, yang artinya: "Allah memusnahkan riba dan menyuburkan sedekah. Dan Allah tidak menyukai setiap orang yang tetap dalam kekafiran, dan selalu berbuat dosa."

Disamping itu, juga mendasarkan pada As-Sunnah. Disebutkan dalam hadits shahih dari Jabir bin 'Abdillah, dia DOI: https://doi.org/10.29313/aktualita.v0i0.5961 menuturkan: "Rasulullah saw., melaknat orang yag memakan riba, yang memberinya makan, juru tulis dan kedua sanksinya. Beliau bersabda,"Mereka itu sama."(HR. Muslim) Dalam hadits yang lain, Rasulullah saw,. Bersabda:"Yang halal itu demikian, jelas, dan yang haram pun demikian jelas. Dan diantara keduanya terdapat beberapa samara masalah yang samar-samar, yang tidak diketahui oleh banyak orang....."

Tampaknya, fatwa diatas ingin benar memisahkan antara yang halal dengan yang haram. Bahwa sesuatu yang halal tidak dapat dicampur dengan yang haram, demikian juga sebaliknnya. Umat Islam dilarang untuk memanfaatkan sesuatu yang bersumber dari yang haram, meskipun hal itu digunakan untuk sesuatu yang bersifat baik.

\section{Kondisi Penerapan Prinsip Syariah} Oleh LKS Di Indonesia.

LKS harus menselaraskan operasionalnya dirinya sesuai dengan fatwa DSN-MUI. Namun, lain dikata, lain realita, ternyata banyak praktek LKS yang bertentangan dengan fatwa 
DSN MUI sehingga menabrak batas batas syariah.

Untuk membuktikan hal itu, mari kita adakan perbandingan antara fatwa DSN (Dewan syariah Nasional) MUI dengan praktek yang diterapkan di LKS. Semoga perbandingan ini menjadi temuan positif bagi semua kalangan yang peduli dengan perkembangan LKS di negeri kita dan untuk selanjutnya dapat dipergunakan memperbaiki operasional.

Fatwa Pertama: tentang Murabahah Kontemporer. Akad Murabahah adalah satu satu produk LKS yang banyak diminati masyarakat. Karena akad ini menjadi alternatif mudah dan tepat bagi berbagai pembiayaan atau kredit dalam perbankan atau lembaga keuangan konvensional yang tentu sarat dengan riba. Kebanyakan ulama dan juga berbagai lembaga fikih nasional atau internasional, membolehkan akad murabahah kontemporer. Lembaga fikih nasional DSN (Dewan Syariah Nasional) di bawah MUI, juga membolehkan akad murabahah, sebagaimana dituangkan dalam fatwanya No: 04/DSNMUI/IV/2000. (Agustin Erlina, 2010 : 210).

DOI: https://doi.org/10.29313/aktualita.v0i0.5961
Fatwa DSN ini, menjadi payung dan pedoman bagi perbankan syariah dalam menjalankan akad murabahah. DSN pada fatwanya No: 04/DSN-MUI/IV/200, tentang Murabahah menyatakan: "Bank membeli barang yang diperlukan nasabah atas nama bank sendiri, dan pembelian ini harus sah dan bebas riba." (Himpunan Fatwa Dewan syariah Nasional MUI, 2008 : 24).

LKS manakah yang benarbenar menerapkan ketentuan ini, sehingga barang yang diperjualbelikan benar-benar telah dibeli. Pada prakteknya, perbankan dan LKS syariah, hanya melakukan akad murabahah bila nasabah telah terlebih dahulu melakukan pembelian dan pembayaran sebagian nilai barang.

Tentu anda mengetahui bahwa perbankan di negeri kita, baik yang berlabel syariah atau tidak, hanyalah berperan sebagai badan intermediasi. Artinya, bank hanya berperan dalam pembiayaan, dan bukan membeli barang, untuk kemudian dijual kembali. Karena secara regulasi dan faktanya, bank maupun LKS tidak dibenarkan untuk melakukan praktek perniagaan praktis. Dengan ketentuan ini, bank tidak mungkin bisa membeli 
yang diperlukan nasabah atas nama bank sendiri. Hasilnya, bank telah melanggar ketentuan DSN-MUI di atas secara terang.

Fatwa Kedua, Tentang Akad Mudharabah (Bagi Hasil). Akad Mudharabah adalah akad yang oleh para ulama telah disepakati akan kehalalannya. Karena itu, akad ini dianggap sebagai tulang punggung praktek perbankan syariah. DSN-MUI telah menerbitkan fatwa no: 07/DSNMUI/IV/2000, yang kemudian menjadi pedoman bagi praktek perbankan syariah. Tapi, lagi-lagi, praktek LKS perlu ditinjau ulang.

Pada fatwa dengan nomor tersebut, DSN menyatakan: "LKS (lembaga Keuangan Syariah) sebagai penyedia dana, menanggung semua kerugian akibat dari mudharabah kecuali jika mudharib (nasabah) melakukan kesalahan yang disengaja, lalai, atau menyalahi perjanjian.” Pada ketentuan lainnya, DSN kembali menekankan akan hal ini dengan pernyataan: "Penyedia dana menanggung semua kerugian akibat dari mudharabah, dan pengelola tidak boleh menanggung kerugian apapun, kecuali diakibatkan dari kesalahan disengaja, kelalaian, atau pelanggaran kesepakatan."

Praktek LKS sebenarnya di lapangan masih jauh dari apa yang di fatwakan oleh DSN. Andai perbankan syariah maupun LKS benar-benar menerapkan ketentuan ini, niscaya masyarakat berbondong-bondong mengajukan pembiayaan dengan skema mudharabah. Dalam waktu singkat pertumbuhan perbankan syariah akan mengungguli perbankan konvensional. Namun kembali lagi, fakta tidak semanis teori. (Umar Chapra, 2000 : 204- 211).

Perbankan syariah maupun LKS yang ada belum sungguhsungguh menerapkan fatwa DSN secara utuh. Sehingga pelaku usaha yang mendapatkan pembiayaan modal dari perbankan syariah, masih diwajibkan mengembalikan modal secara utuh, walaupun ia mengalami kerugian usaha.

Terlalu banyak fakta dari nasabah mudharabah bank syariah yang mengalami perlakuan ini. Fatwa Ketiga, Tentang Gadai Emas, Gadai emas merupakan cara investasi yang marak ditawarkan perbankan syariah akhir-akhir ini. Gadai emas mencuat 
dan diminati banyak orang sejak harga emas terus membumbung tinggi.

Dewan Syariah Nasioanal melalui fatwanya no: 25/DSNMUI/III/2002membolehkan praktek ini. Pada fatwa tersebut DSN menyatakan: "Besar biaya pemeliharaan dan penyimpanan marhun (barang gadai) tidak boleh ditentukan berdasarkan jumlah pinjaman." Sementara dalam fatwa DSN No: 26/DSN-MUI/III/2002 yang secara khusus menjelaskan aturan gadai emas, dinyatakan:

"Ongkos sebagaimana dimaksud ayat 2 besarnya didasarkan pada pengeluaran yang nyata-nyata diperlukan.

Fakta dilapangan membuktikan bahwa LKS yang ada, telah memungut biaya administrasi pemeliharan dan penyimpanan barang gadai sebesar persentase tertentu dari nilai piutang. Jika LKS atau perbankan syariah bersedia menerapkan fatwa di atas, tentunya dalam menentukan biaya pemeliharaan emas yang digadaikan, bank akan menentukan berdasarkan harga Safe Deposit Box (SDB). Akan tetapi, fakta menunjukkan bahwa ongkos penyimpanan yang DOI: https://doi.org/10.29313/aktualita.v0i0.5961 dibebankan nasabah TIDAK sesuai dengan biaya riil yang dibutuhkan untuk standar penyimpanan dan penjagaan bank, atau melebihi nilai harga SDB untuk penyimpanan emas. Dus, lagi-lagi praktek perbankan/LKS syariah nyata-nyata melanggar fatwa DSN. (Muhammad, 2009 : 33).

$\begin{array}{crc}\text { Ketidak } & \text { syariahan } & \text { bank } \\ \text { syariah justru dalam taraf }\end{array}$ mendasarnya yaitu ketidak sesuaian operasional dengan fatwa DSN, Menerapkan Hilah dengan mengistinbathkan denganhal yang tidak sesuai. Ketidak sesuaian LKS maupun bank syariah ini pada akhirnya diakui oleh direktur direktorat perbankan syariah Mulya E. Siregar menyatakan bahwa perbankan syariah belum benar benar menerapkan system syariah. Menurut Mulya tidak ada Bank Syariah yang benar-benar syariah, bahkan IDB sekalipun.

Ungkapan Direktur BI ini merupakan sesuatu yang riil bahwa perbankan maupun LKS belum ada yang benar benar berprinsip sesuai syariah walaupun sangat mengejutkan karena segenap peraturan, bahkan dibuat struktur guna pengawasan pun masih belum sepenuhnya sesuai 
syariah. Menjadi kebutuhan untuk LKS agar dapat hidup dan berkembang dan yang terpenting sesuai dengan syariah.

\section{PENUTUP}

\section{Kesimpulan}

1. Penerapan prinsip syariah bagi Lembaga Keuangan Syariah (LKS) maupun perbankan syariah adalah hal yang sangat urgen. Demi mencapai kondisi penerapan syariah tersebut diciptakan struktur pengawasan maupun penerapannya serta dipandu dengan fatwa Dewan Syariah Nasional. Undang-Undang maupun peraturan lain telah mensupport sebagian dari tujuan tersebut namun masih ada regulasi yang belum. Masih terdapat ketidaksesuaian praktik perbankan maupun LKS yang tidak sesuai fatwa DSN atau tidak sesuai syariah dan perlu untuk dibenahi. Terdapat LKS yang melakukan hilah atau trik guna mengambil riba.

2. Dengan berlakunya Peraturan Bank Indonesia No. 11/3/PBI/2009 maka hilang juga ketentuan tentang kepastian modal Bank Syariah tidak berasal dari sumber dana yang diharamkan menurut prinsip syariah. Sehingga dengan demikian akan berpotensi juga bercampurnya uang haram dengan uang DOI: https://doi.org/10.29313/aktualita.v0i0.5961 halal, apabila modal bank Syariah sudah secara tegas ditentukan bahwa antara yang haram dengan yang halal harus dipisahkan. Sesuatu yang halal tidak dapat dicampur dengan yang haram, demikian juga sebaliknya. Umat Islam dilarang untuk memanfaatkan sesuatu yang bersumber dari yang haram, meskipun hal itu digunakan untuk sesuatu yang bersifat baik.

\section{Saran}

1. LKS sebagai lembaga keuangan dengan prinsip syariah awalnya hadir sebagai pilihan sekaligus solusi untuk muslim yang ingin terhindar dari praktek bank atau lembaga keuangan konvensional yang menggunakan system riba harus meningkatkan peran dan fungsinya untuk dapat mengakomodir bagi umat muslim dan selain umat muslim.

2. Penyelenggaraan LKS wajib bertanggung jawab secara syariah untuk menjaga tidak hanya agar praktek dalam LKS itu bebas riba saja tapi juga harus bebas dari unsur unsur maysir dan Gharar. Islam memerintahkan untuk menjauhi halhal tersebut karena hal tersebut dianggap sebagai berbuat zhalim atau kerusakan Penyelenggara LKS dituntut memiliki tidak hanya visi bisnis an sich yang bertujuan mengeruk laba yang setinggitingginya dengan mengesampingkan syariah namun juga harus memiliki visi syariah. 


\section{DAFTAR PUSTAKA}

\section{A. Buku}

Abdul Ghofur Anshori, Penerapan Syariah Dalam Lembaga Keuangan, Lembaga Pembiayaan dan Perusahaan Pembiayaan, Pustaka Pelajar, Yogyakarta, 2008

Adiwarman A.Karim. 2007. Ekonomi Mikro Islam. Jakarta: RajaGrafindo Persada.

Agustin Erlina, Manajemen Resiko Perbankan Syariah, Mizan Publika, Jakarta, 2010

Himpunan Fatwa Dewan syariah Nasional MUI, 2008

M. Abdul, Ghoffar (2004).Tafsir Ibnu Katsir,Bogor: Pustaka Imam AsySyafi' I

Muhammad. Model-model Akad Pembiayaan di Bank Syariah. Yogyakarta: UII Press, 2009

Rivai, Veithzal dan Arviyan Arifin. Islamic Banking: Sebuah Teori, Konsep, dan Aplikasi, Jakarta: Bumi Aksara. 2010

Umar Chapra, Islam dan Tantangan Ekonomi, Penerjemah Ikhwan Abidin, B.Gema Insani, Jakarta, 2000

\section{B. Jurnal}

Arief Budiono, Penerapan Prinsip Syariah Pada Lembaga Keuangan Syariah, Universitas Muhammadiyah Ponorogo, Jurnal Law And Justice Vol. 2 No. 1 April 2017

Neni Sri Imaniyati, Pengaruh Perbankan Syariah Terhadap Hukum Perbankan Nasional, Fakultas Hukum Universitas Islam Bandung, Syiar Madani, Vo.Iv No. 1 Maret 2002

Yusman Alim Djasmin Maku, Penerapan Prinsip-Prinsip Tentang Perbankan Syariah Hubungannya Dengan Otoritas Jasa Keuangan, Lex Crimen Vol. Vi/No. 1/Jan-Feb/2017 